\title{
Overview of the influences of mining-related pollution on the water quality of the Mooi River system's reservoirs, using basic statistical analyses and self organised mapping
}

\author{
S Barnard ${ }^{1 *}$, A Venter $^{1}$ and CE van Ginkel ${ }^{2}$ \\ 'Unit for Environmental Science and Management, North-West University, Potchefstroom, 2520, South Africa \\ ${ }^{2}$ Cripsis Environment, $59020^{\text {th }}$ Avenue, Rietfontein, 0084, South Africa
}

\begin{abstract}
The Mooi River catchment, in particular the Wonderfonteinspruit (WFS), has been the subject of a large number of studies regarding significant pollution sources, generally attributed to mining in the area. However, very little is known about the hydrochemistry of the surface water of the Klerkskraal, Boskop and Potchefstroom Dams in the Mooi River catchment. The aim of this study was to identify any hydro-chemical changes that occurred in the water quality of Klerkskraal, Boskop and Potchefstroom Dams during the period 1995 to 2010. Self-organised mapping (SOM) of the data emphasized the influence of mining-related effluents on the quality of the freshwater resources of the Boskop Dam and Potchefstroom Damrelative to Klerkskraal Dam which is located upstream of mining-related influences and which could therefore serve as a reference site. High concentrations of $\mathrm{SO}_{4}$ together with high electrical conductivity (EC) and total dissolved solids (TDS) values were evident in these dams as compared to Klerkskraal Dam. Concentrations of nutrients such as $\mathrm{PO}_{4}, \mathrm{NH}_{4}$ and $\mathrm{NO}_{3}+\mathrm{NO}_{2}$ were however low in all three reservoirs. In Klerkskraal Dam, which is situated above the confluence of the WFS, a strong direct relationship between EC and total alkalinity (TAL) was exhibited. This suggests that Klerkskraal Dam is still a water source displaying natural unpolluted conditions, where increases in EC, TDS and TAL can be explained by natural dissolution of the bedrock. Boskop Dam presents a dam impacted by pollutants with no direct correlation between EC and TAL. During the current study both $\mathrm{SO}_{4}$ concentrations as well as $\mathrm{Na}^{+}$concentrations exhibited a decline from 1995 until 2010 in Boskop Dam. This suggests that, although Boskop Dam still carries the burden of mining pollution via the WFS, the pollution levels of the freshwater of Boskop Dam have decreased between 1995 and 2010.
\end{abstract}

Keywords: self-organised mapping, water quality, electrical conductivity, alkalinity, sulphates, Boskop Dam, Potchefstroom Dam, Klerkskraal Dam, Wonderfonteinspruit

\section{INTRODUCTION}

The Mooi River catchment includes several reservoirs, the largest of which is the Klerkskraal Dam. During the past decade the Mooi River catchment, in particular the Wonderfonteinspruit (WFS), has been the subject of a large number of studies conducted by the Department of Water Affairs and Forestry (DWAF), Council for Scientific and Industrial Research (CSIR) and Water Research Commission (WRC) (IWQS, 1999; Coetzee et al., 2002; Wade et al., 2002; Coetzee et al., 2006; Winde 2010a,b) regarding significant radioactive and other pollution sources, generally attributed to the mining in the area and the processing of gold ores rich in uranium.

A potential for downstream contamination was identified as a specific concern for the water supply of the city of Potchefstroom (Coetzee et al., 2002). Potchefstroom is located downstream of the confluence of the WFS and Mooi River. All 250000 inhabitants of the city of Potchefstroom receive their drinking water from the Boskop and Potchefstroom Dams (Annandale and Nealer, 2011). Geohydrologically as well as hydrochemically, the WFS have been studied in detail; very little is known, however, about hydrochemistry of the surface waters of the Klerkskraal, Boskop and Potchefstroom Dams.

To whom all correspondence should be addressed.

iㅛ +2718-299 2508; fax: +2718-299 2370;

e-mail: sandra.barnard@nwu.ac.za

Received 14 November 2012; accepted in revised form 23 September 2013.
When mining companies obtain prospecting permits for minerals, including gold, diamonds, uranium, tungsten, iron ore, thorium and selenium, in the Mooi River catchment area close to Potchefstroom, questions are raised regarding the future impact on drinking water quality. New mining activity may become a reality, as mining companies such as New Heights 147, Wits Gold and Miranda Mineral Holdings have already obtained prospecting permits for the area east of Boskop Dam (Louw, 2011a; Louw, 2011b).

The aim of this study was to identify any hydrochemical differences between as well as changes that have occurred in the water quality of Klerkskraal, Boskop and Potchefstroom Dams over the period 1995-2010. These results can then be used as a baseline for monitoring the impacts on water quality that may occur if proposed mining activities take place in the future. During this study we mainly concentrated on the parameters EC, TAL, pH, TDS, $\mathrm{SO}_{4}, \mathrm{Ca}, \mathrm{Mg}$ and $\mathrm{Na}$. Kney and Brandes (2007) hypothesized that alkalinity values can be used as an index of bedrock geology and that it can be expected that, under natural conditions, a particular range of EC values will correspond to a particular range of alkalinity. Ionic pollutants from anthropogenic sources contribute to EC, however, and it is this portion of the EC that should be of primary interest to monitoring and assessment. Kney and Brandes (2007) suggest that anthropogenic impacts will result in a deviation in the relationship between EC and alkalinity and it should therefore be possible to use concurrent alkalinity and EC measurements to indicate anthropogenic impacts. 
During this study we also made use of self-organised mapping (SOM) methodology, a relatively novel modelling method that can be applied to various types of data (Van Ginkel, 2008). SOM methodology has been applied successfully to different environmental, ecological and climatic studies (Van Ginkel, 2008; Kalteh et al., 2008; Chan et al., 2007). SOM is an unsupervised neural network method which has properties of both vector quantisation and vector projection algorithms, as developed by Kohonen (1982; 1988), but may make use of supervised pre-classification of the data to assist in the training of the network (Kohonen, 1995). The primary application for SOM toolboxes is clustering and data segmentation. SOM requires that data contain inputs that describe the characteristics of the variables or fields. The network then learns to ordinate and cluster or segment the data based on similarities or differences in the input variables only (Recknagel et al., 2006).

\section{Hydrological overview and land-use of the Mooi River catchment}

The Mooi River has 3 major sub-catchments, namely the WFS (north-eastern reach), the Mooi River proper (northern reach) and the Loopspruit (eastern reach) (Van der Walt et al., 2002). The headwaters of the Mooi River rise at an altitude of approximately $1650 \mathrm{~m}$ amsl near the town of Derby in the North West Province (Currie, 2001), and flow south through rural and agricultural land into the Klerkskraal, Boskop and Potchefstroom Dams, from where the river meanders to join the Vaal River (Fig. 1)

The Mooirivierloop, a tributary of the Mooi River upstream from Boskop Dam, is fed by water from the WFS during high rainfall conditions. The WFS has its origin in the Tudor and Lancaster areas south of Krugersdorp, where it drains parts of the Krugersdorp area south of the Indian/Atlantic watershed. The Donaldson Dam in the upper WFS receives water from diverse sources, such as sewage facilities, mining areas and informal settlements.

The lower WFS, downstream of the Donaldson Dam, represents a combination of artificial and natural drainage. Most of the water is conveyed via a pipeline until it reaches the Oberholser underground compartment. From here the water flows to the natural streambed in a canal. If the stormwater exceeds the capacity of the pipeline, the water is discharged across a side-spill weir into the original WFS streambed feeding the Mooirivierloop (Winde, 2010a).

According to Winde (2010 b), the WFS dries up before it joins the Mooi River, but can indirectly reach Potchefstroom, since much of the water from the WFS recharges the underlying karst aquifer of the Boskop-Turffontein Compartment, the single most important water resource for Boskop Dam and thus Potchefstroom. Groundwater moves rapidly in large volumes through large solution cavities in the dolomite. This groundwater flow, along with the WFS, forms a continuous link between mining areas. The dewatering of these compartments, result in severe impacts on both quality and quantity of the WFS, especially in the form of increased salinity and high sulphate concentrations (Winde, 2010b).

The predominant land-uses in the northern sub-catchment are crop farming and grazing (Van der Walt et al., 2002). The soils and climate of the Mooi River catchment are suitable for a moderate range of agricultural products, and the principal land uses are dryland maize and sunflower cultivation as well as cattle ranching. According to DWA (1986), two major activities accelerate the input of salts to inland waters from essentially

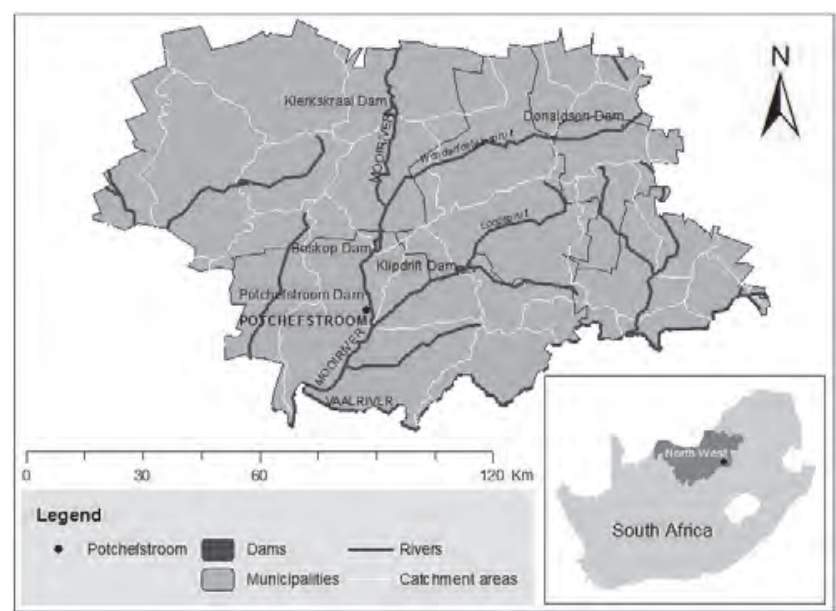

Figure 1

Catchment of the Mooi River from source to the confluence with the Vaal River

natural sources, namely, irrigation and dryland farming, following the removal of natural vegetation. Because the soil of farms in the area has been under irrigation for the past 75 years, the aggregate structure of the soil has changed, resulting in a finer, less stable soil, resulting in erosion and loss of topsoil with run-off.

Peat mining in the tributary that is formed from the Gerhard Minnebron dolomitic eye has reduced the habitat integrity in this part of the catchment (DWA, 2009).

Some small-scale diamond diggings also occur in the stream channel of the Mooi River between Klerkskraal Dam and Boskop Dam, destroying the floodplain and riparian habitats and resulting in silting of the Mooi River upstream of Boskop Dam (Van der Walt et al., 2002). This has had the result of altering the channel course (Currie, 2001).

\section{STUDY SITES}

\section{Klerkskraal Dam}

The Klerkskraal Dam is situated north of the VentersdorpKrugersdorp provincial road, $30 \mathrm{~km}$ east of Ventersdorp. To better manage irrigation and flow from the Mooi River, the Klerkskraal Dam and its western and eastern banks' cement canals were completed in 1971 (Annandale and Nealer, 2011). The dam has a catchment area of $1324 \mathrm{~km}^{2}$, capacity of $8 \mathrm{Ml}$, and a surface area of 383 ha (Annandale and Nealer, 2011; DWA, 2011).

\section{Boskop Dam}

Due to a shortage of irrigation water, construction of the Boskop Dam and distribution canals was completed in 1959 (Annandale and Nealer, 2011). The Boskop Dam is founded on fairly complex geology consisting of a quartzite ridge, shale, lava, dolomitic limestone, a number of faults and a diabase dyke (Annandale and Nealer, 2011 and references therein). The source water of Boskop Dam originates from dolomite underground compartments, of which the Boskop-Turffontein Compartment and Gerhard Minnebron eye are the main sources (DWAF, 1999). Boskop Dam has a catchment area of $3287 \mathrm{~km}^{2}$, a capacity $20 \mathrm{Ml}$, and a surface area of $373 \mathrm{ha}$ (DWA, 2011). 


\section{Potchefstroom Dam}

A growing need for irrigation water in Potchefstroom and surrounding areas after the Anglo-Boer war led to the building of Potchefstroom Dam, completed in1910 (Annandale and Nealer, 2011). The Potchefstroom Dam is a Category 2 Dam and has a catchment area of $3632 \mathrm{~km}^{2}$, a capacity of $2 \mathrm{Ml}$, and a surface area of 77.3 ha (DWA, 2011). Although the dam was built mainly for irrigation purposes, it has become an important recreational venue (Annandale and Nealer, 2011).

\section{METHODS}

Data from 1995-2010 for the physical and chemical parameters were obtained from the Department of Water Affairs. The data consist of measurements of: surface temperature - Tsurf $\left({ }^{\circ} \mathrm{C}\right)$, electrical conductivity - EC $(\mathrm{mS} / \mathrm{m})$, total alkalinity - TAL $\left(\mathrm{mg} / \ell \mathrm{CaCO}_{3}\right), \mathrm{pH}$, total dissolved solids - TDS (mg/l), sodium - $\mathrm{Na}(\mathrm{mg} / \mathrm{\ell})$, calcium - $\mathrm{Ca}(\mathrm{mg} / \ell)$, magnesium - $\mathrm{Mg}(\mathrm{mg} / \ell)$, sulphates $-\mathrm{SO}_{4}(\mathrm{mg} / \ell)$, nitrate + nitrite $-\mathrm{NO}_{3}+\mathrm{NO}_{2}(\mathrm{mg} / \ell)$, ammonia $-\mathrm{NH}_{4}(\mathrm{mg} / \ell)$, and orthophosphate $-\mathrm{PO}_{4}(\mathrm{mg} / \mathrm{\ell})$ from the sampling stations Klerkskraal (C2ROO3Q01, near dam wall), Boskop (C2ROO1Q01, near dam wall) and Potchefstroom (C2ROO4Q01, near dam wall). The annual averages of these parameters were then compared.

\section{SOM mapping of water quality data}

The method used was SOM_QuickPick (Vesanto, 2000), which has an input layer which contains the known variables and a hidden layer which is used to cluster and ordinate the data, with the mapping of the clustered layer as the output; see Fig. 2 (Recknagel et al., 2006). The learning process in the hidden layer is as follows:

- The weight for each output unit is initialised

- The process within SOM cycles until the weight changes are negligible for each input pattern (the present input pattern finds the winning output unit, finds all units in the neighbourhood of the winner and updates the weight vectors for all those units)

- The size of the neighbourhoods is reduced if required (Kohonen and Honkela, 2007)

The input data set was pre-classified using the different dams to classify or categorise the data set.

The input variables, including EC, $\mathrm{pH}$, TAL, TDS, $\mathrm{PO}_{4}$, $\mathrm{NH}_{4}, \mathrm{NO}_{3}$ and $\mathrm{SO}_{4}$ were prepared in the format as required by the SOM_QuickPick toolbox (Vesanto et al., 2000). The normalisation method used within the Matlab toolbox was the 'range' normalisation method as it provides the best values for the final quantization error (FQE) and the final topographic error (FTE). This method of normalisation scales the variable values between $[0,1]$ with a simple linear transformation:

$$
x^{1}=(x-\min (x)) /(\max (x)-\min (x)) .
$$

The transformation parameters are the minimum value and range $(\max (x)-\min (x))$ of the variable. Note that if the transformation is applied to new data with values outside the original minima and maxima, the transformation values will also be outside the $[0,1]$ range.

The SOM_QuickPick then adds the labels according to the manual categorisation. An additional map showing the frequency of certain results within each result was obtained

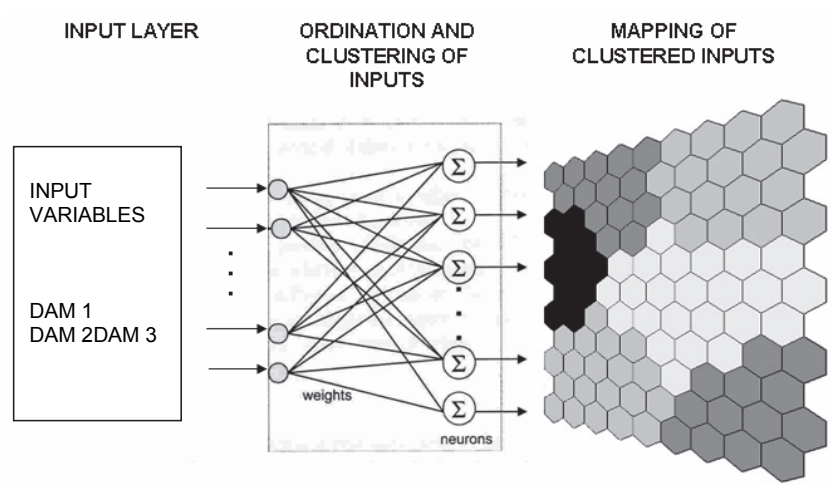

Figure 2

The structure of the non-supervised SOM for ordination and clustering of inputs (redrawn from Recknagel et al., 2006)

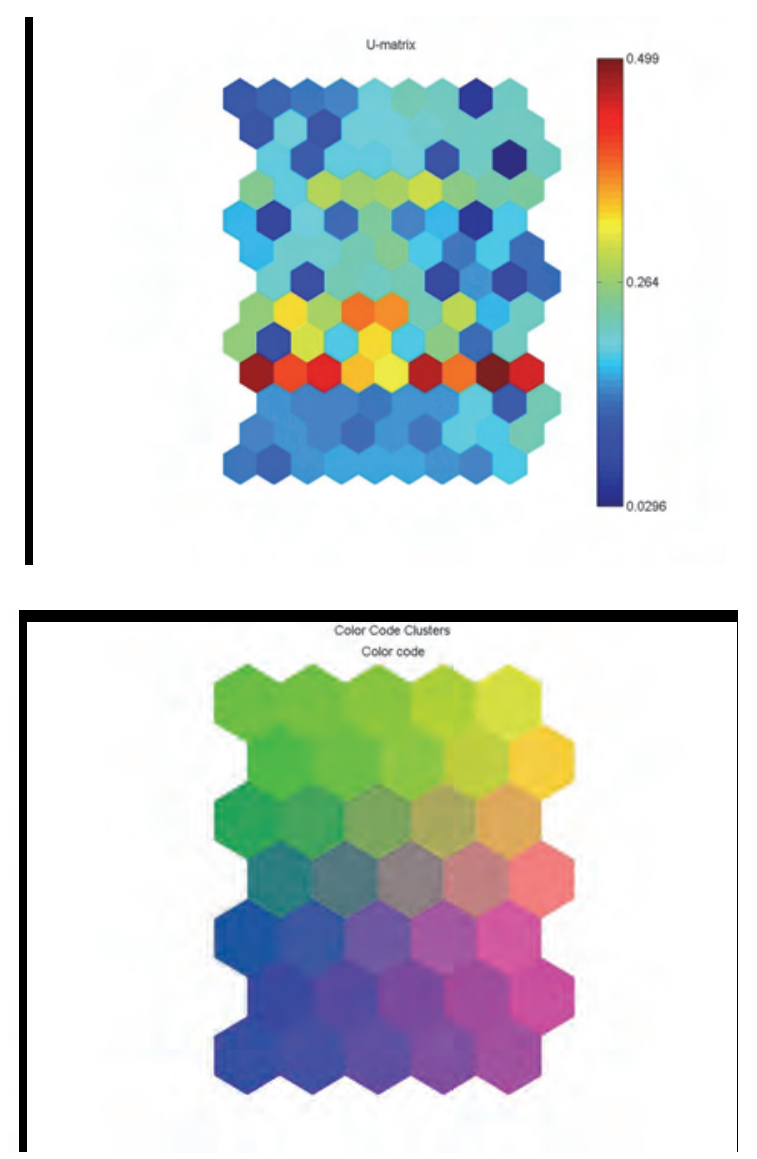

Figure 3

The U-matrix map and the colour-coded clusters as output of SOM

from normalised input data via the Euclidean distance between the input being calculated and then visualised as a distance matrix - the U matrix (a) and a partition map (b) (K-means). The $\mathrm{U}$ matrix is a unified distance matrix for the creation of the self-organising map (Ultsch and Siemon 1990, Kohonen 1995, Iivarinen et al. 1994, Kraaijveld et al. 1995). See Figs. 3 and 4.

The SOM uses colour plane visualisation which is shown as a honeycomb map for the U matrix map, the manual categorisation as linked to the self-organised clusters and the colourcoded range of normalised values for each of the components or variables. The colour-coded range of normalised values for each of the components or input variables allows one to see 


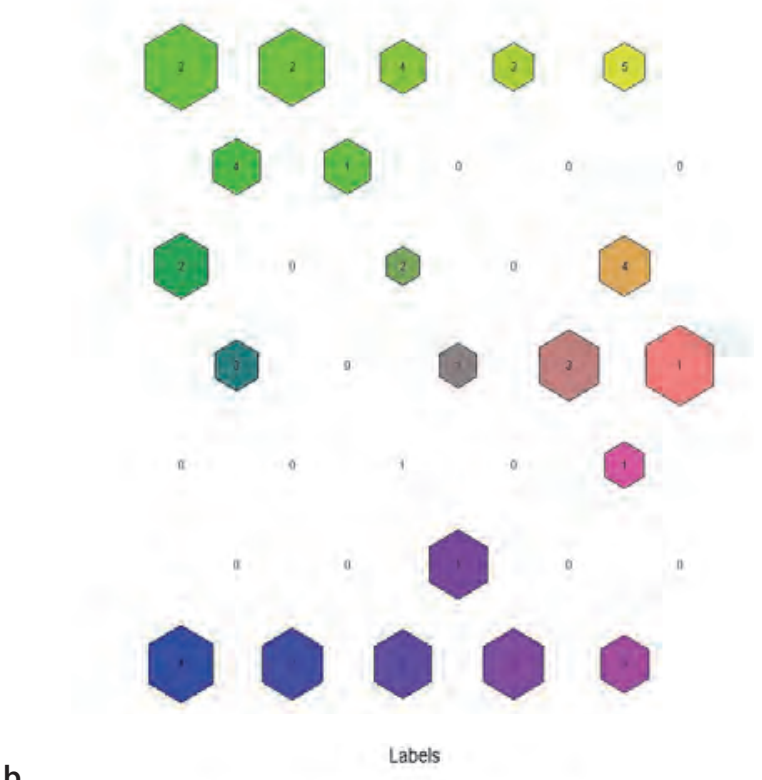

b

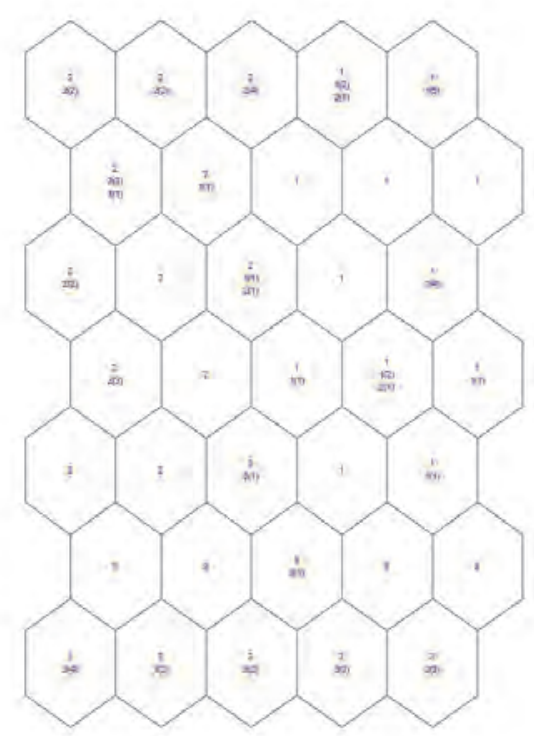

Figure 4

a) The colour-coded map showing the frequency of occurrences and b) labels of the classification as allocated during the clustering procedure

correlations between different components that were organised into nearby, or the same clusters. A label map is created by the SOM_QuickPic and indicates the frequency for all the components within the self-organised clusters according to their location. These labels are then used to compose the partitioned map (Fig. 4b) which is used to interpret the maps of the variables by comparing the location map (a) to the SOM maps produced by the model for each variable.

\section{Statistical analyses}

Statistica version 11 (Statsoft, 2012) software was used to examine the differences between the different datasets for each reservoir. The Kolmogorov-Smirnov and Lilliefors tests for normality were used to determine if the datasets were distributed parametrically. The data did not meet the assumptions of normality in the distribution of all variables. Therefore the non-parametric Kruskal-Wallis ANOVA for comparing multiple independent samples was used to determine differences between the different sampling sites in each reservoir $(p<0.05)$ The time series was investigated graphically using the graph options in Statistica version 11 (Statsoft, 2013). The degree of association or the strength of a linear relationship between two variables was evaluated by calculating the square of the coefficient of correlation, $r^{2}$.

\section{RESULTS}

\section{SOM mapping of water quality data}

The samples were grouped according to location. We successfully used this method to show that the three dams are hydrochemically different especially regarding water quality variables such as EC, TAL, $\mathrm{pH}$ and $\mathrm{SO}_{4}$. Figure 5 demonstrates the difference in the physio-chemical character of the different reservoirs as well as the magnitude of the measured variables.

The component planes in Fig. 5 indicate significant differences in the physical-chemical characteristics of the three reservoirs. Klerkskraal Dam exhibited the lowest values in EC, TAL, TDS and pH, while the Boskop and Potchefstroom Dams clearly exhibited the highest values. Potchefstroom Dam was associated with the highest values recorded for EC and TDS. The statistical differences (Table 1) between the measured values of the different parameters determined in the three reservoirs confirm the results obtained from the SOM. Klerkskraal Dam exhibited significantly lower values for EC (Table 1); however, there was no significant difference observed between the three reservoirs for TDS levels.

The component planes in Fig. 5 show that Klerkskraal Dam, which is situated at the origin of the Mooi River upstream of the confluence with the WFS, had concentrations of $\mathrm{SO}_{4}$ up to 10 times lower than those recorded in Boskop Dam. Boskop Dam was associated with the highest values recorded for $\mathrm{SO}_{4}$. There was a significant difference between $\mathrm{SO}_{4}$ concentrations in Klerkkraal Dam comparedto Boskop and Potchefstroom Dams (Table 1).

The highest concentrations of $\mathrm{NH}_{4}$ and $\mathrm{NO}_{3}+\mathrm{NO}_{2}$ were measured at Boskop Dam, as revealed by differences in the nutrient clustering patterns between the three reservoirs (Fig. 6). The concentrations were up to 10 times more in Boskop Dam than in Klerkskraal Dam. No significant difference was observed between the reservoirs when comparing $\mathrm{PO}_{4}$ concentrations in the ANOVA analysis (Table 1). It is evident form the component planes in Fig. 6 that the highest concentrations were observed in the Potchefstroom Dam, with most of the lower concentrations measured in the Boskop Dam.

\section{Time series and general statistics of water quality data}

The average annual $\mathrm{pH}$ of all three reservoirs varied between 8.0 and 8.8 . The yearly average $\mathrm{pH}$ in all three reservoirs showed a decreasing trend during the study period (1995-2010). The $\mathrm{pH}$ in the Boskop Dam declined slightly from 8.56 to 8.15 and in Klerkskraal Dam from 8.34 in 1996 to 8.01 in 2010. No significant difference in $\mathrm{pH}$ could be detected between the three reservoirs (Table 1).

Alkalinity can be seen as a measure of the buffering capacity of the water (Dallas and Day, 2004), and is primarily controlled by carbonate species and is therefore usually expressed in terms of equivalence to calcium carbonate 


\begin{tabular}{|c|c|c|c|}
\hline $\begin{array}{l}\text { The stati } \\
\text { the differ } \\
\text { accordin } \\
\text { Dam; } \\
\text { shadec }\end{array}$ & $\begin{array}{l}\text { al differen } \\
\text { parameter } \\
\text { o the Krusk } \\
\text { otchefstro } \\
\text { lues indica } \\
\text { tween two }\end{array}$ & $\begin{array}{l}\text { LE } 1 \\
\text { ween the } \\
\text { rmined in } \\
\text { Ilis test } \mathrm{H} \text { ( } \\
\mathrm{m} \text {; (3) Kler } \\
\text { ificant diff } \\
\text { re of the re }\end{array}$ & $\begin{array}{l}\text { ed values of } \\
\text { e reservoirs } \\
\text { (1) Boskop } \\
\text { Dam. The } \\
\text { s }(p<0.05) \\
s \text {. }\end{array}$ \\
\hline Parameter & Multip & parison $p \mathrm{v}$ & tailed) \\
\hline EC & $\begin{array}{c}1 \\
R: 27.71\end{array}$ & $\begin{array}{c}2 \\
R: 34.81\end{array}$ & $\begin{array}{c}3 \\
R: 8.50\end{array}$ \\
\hline 1 & & 0.45 & $2.75 \mathrm{E}-04$ \\
\hline 2 & 0.45 & & 0.000000 \\
\hline 3 & $2.75 \mathrm{E}-04$ & 0.00 & \\
\hline pH & $\begin{array}{c}1 \\
R: 26.94\end{array}$ & $\begin{array}{c}2 \\
R: 28.56\end{array}$ & $\begin{array}{c}3 \\
R: 18.00\end{array}$ \\
\hline 1 & & 1.00 & 0.21 \\
\hline 2 & 1.00 & & 0.10 \\
\hline 3 & 0.21 & 0.10 & \\
\hline TDS & $\begin{array}{c}1 \\
R: 24.67 \\
\end{array}$ & $\begin{array}{c}2 \\
R: 35.71 \\
\end{array}$ & $\begin{array}{c}3 \\
R: 8.00\end{array}$ \\
\hline 1 & & 2.31 & 3.55 \\
\hline 2 & 2.31 & & 5.8 \\
\hline 3 & 3.55 & 5.81 & \\
\hline TAL & $\begin{array}{c}1 \\
R: 25.38 \\
\end{array}$ & $\begin{array}{c}2 \\
R: 33.06 \\
\end{array}$ & $\begin{array}{c}3 \\
R: 15.06 \\
\end{array}$ \\
\hline 1 & & 0.36 & 0.11 \\
\hline 2 & 0.36 & & $8.29 \mathrm{E}-04$ \\
\hline 3 & 0.11 & $8.29 \mathrm{E}-04$ & \\
\hline $\mathrm{SO}_{4}$ & $\begin{array}{c}1 \\
R: 33.25 \\
\end{array}$ & $\begin{array}{c}2 \\
R: 31.75\end{array}$ & $\begin{array}{c}3 \\
R: 8.50 \\
\end{array}$ \\
\hline 1 & & 1.00 & $2.00 \mathrm{E}-06$ \\
\hline 2 & 1.00 & & $8.00 \mathrm{E}-06$ \\
\hline 3 & $2.00 \mathrm{E}-06$ & $8.00 \mathrm{E}-06$ & \\
\hline $\mathrm{NH}_{4}$ & $\begin{array}{c}1 \\
R: 30.62\end{array}$ & $\begin{array}{c}2 \\
R: 26.00\end{array}$ & $\begin{array}{c}3 \\
R: 16.88\end{array}$ \\
\hline 1 & & 1.00 & 0.02 \\
\hline 2 & 1.000000 & & 0.20 \\
\hline 3 & 0.02 & 0.20 & \\
\hline $\mathrm{NO}_{3}$ & $\begin{array}{c}1 \\
R: 39.31\end{array}$ & $\begin{array}{c}2 \\
R: 22.81\end{array}$ & $\begin{array}{c}3 \\
R: 11.38\end{array}$ \\
\hline 1 & & $2.57 \mathrm{E}-0$ & 0.00 \\
\hline 2 & $2.57 \mathrm{E}-03$ & & 0.06 \\
\hline 3 & 0.00 & 0.06 & \\
\hline $\mathrm{PO}_{4}$ & $\begin{array}{c}1 \\
R: 19.47 \\
\end{array}$ & $\begin{array}{c}2 \\
R: 30.50 \\
\end{array}$ & $\begin{array}{c}3 \\
R: 23.53 \\
\end{array}$ \\
\hline 1 & & 0.08 & 1.00 \\
\hline 2 & 0.08 & & 0.48 \\
\hline 3 & 1.00 & 0.48 & \\
\hline
\end{tabular}

$R$ is the rank value.

(DWAF, 1996). The average annual alkalinity in all three reservoirs increased during the study period, along with EC. Figure 7 exhibits the changes in EC and TAL in Boskop Dam. Similar results were obtained for Potchefstroom Dam (results not shown). In Klerkskraal Dam both EC and TAL also showed an increase over the study period. A strong direct relationship $\left(r^{2}=0.90\right)$ between EC and TAL as well as
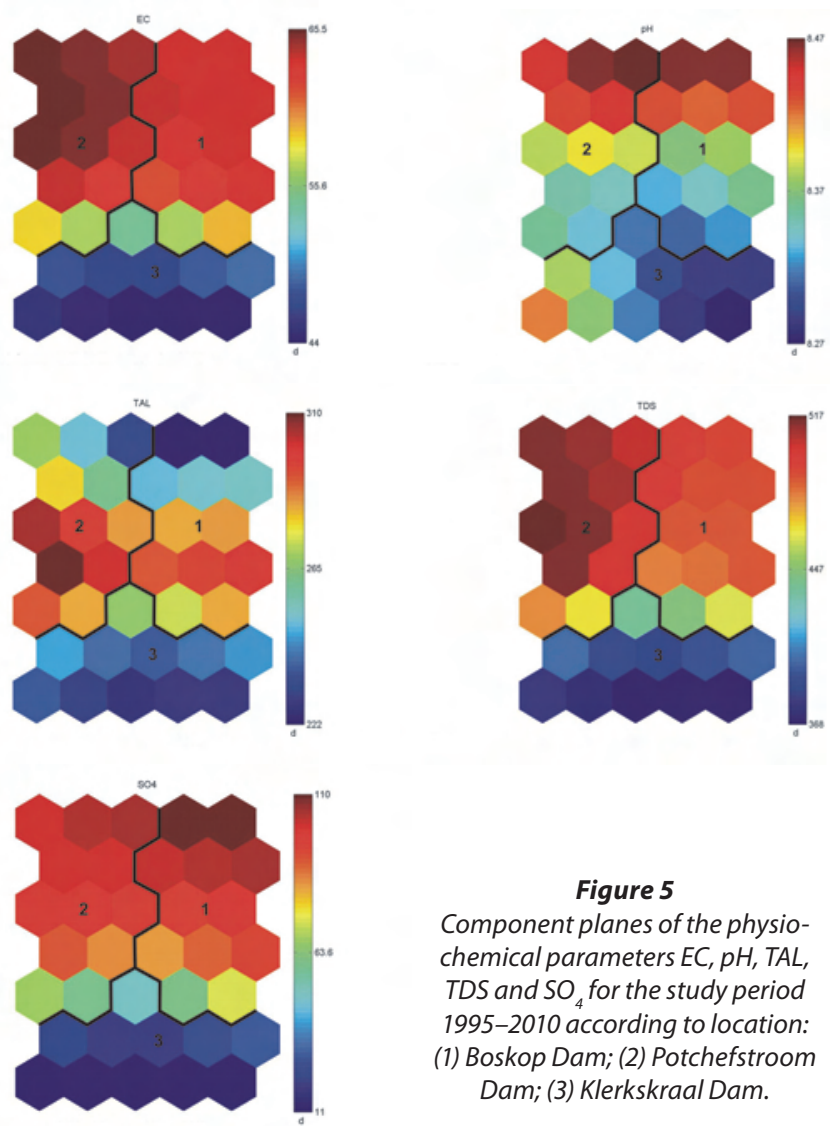

Figure 5

Component planes of the physiochemical parameters $E C, p H, T A L$, TDS and $\mathrm{SO}_{4}$ for the study period 1995-2010 according to location: (1) Boskop Dam; (2) Potchefstroom Dam; (3) Klerkskraal Dam.
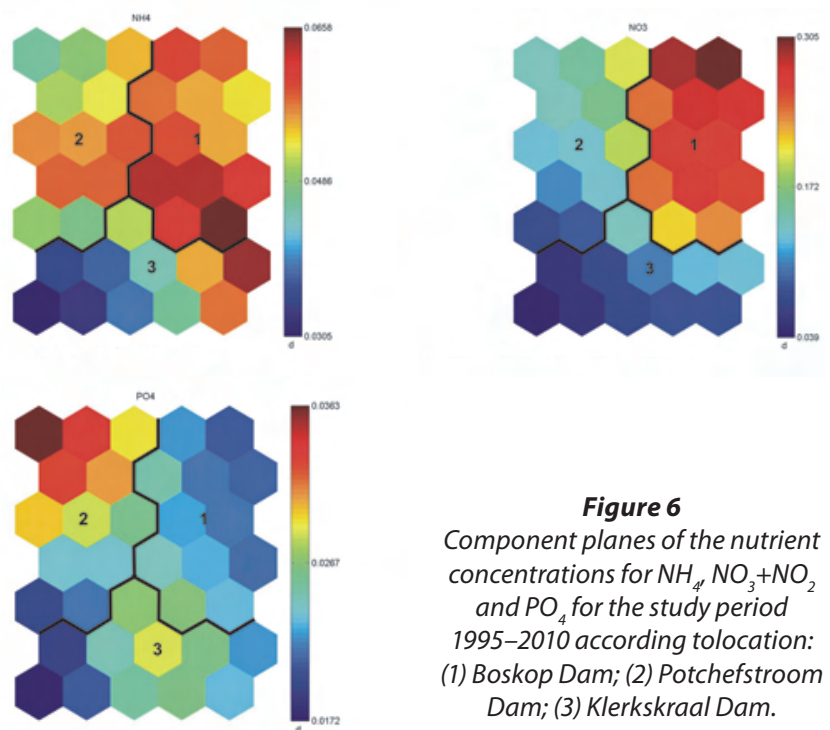

Figure 6

Component planes of the nutrient concentrations for $\mathrm{NH}_{4} \mathrm{NO}_{3}+\mathrm{NO}_{2}$ and $\mathrm{PO}_{4}$ for the study period 1995-2010 according tolocation: (1) Boskop Dam; (2) Potchefstroom Dam; (3) Klerkskraal Dam.

between EC and TDS $\left(r^{2}=0.82\right)$ could be shown (Fig. 7).

Average annual $\mathrm{SO}_{4}$ concentrations in Boskop Dam decreased from a maximum in 1995 of $133.15 \mathrm{mg} / \ell$ to a minimum in 2010 of $58.86 \mathrm{mg} / \ell$, as did $\mathrm{Na}$ concentrations, which decreased from $25.06 \mathrm{mg} / \ell$ in 1998 to a minimum of 14.58 $\mathrm{mg} / \mathrm{\ell}$ in 2010 (Fig. 8). Despite these decreases the average annual Ca concentration increased from $48.01 \mathrm{mg} / \ell$ in 1995 to $58.15 \mathrm{mg} / \ell$ in 2009 , while the $\mathrm{Mg}$ concentration increased from $38.6 \mathrm{mg} / \ell$ in 1996 to $47,4 \mathrm{mg} / \ell$ in 2009 . Similar changes in $\mathrm{SO}_{4}, \mathrm{Na}, \mathrm{Ca}$ and $\mathrm{Mg}$ concentrations were also observed in Potchefstroom Dam, but to a lesser degree. No clear trends in the concentrations of $\mathrm{SO}_{4}$ and $\mathrm{Na}$ emerged from the data for 

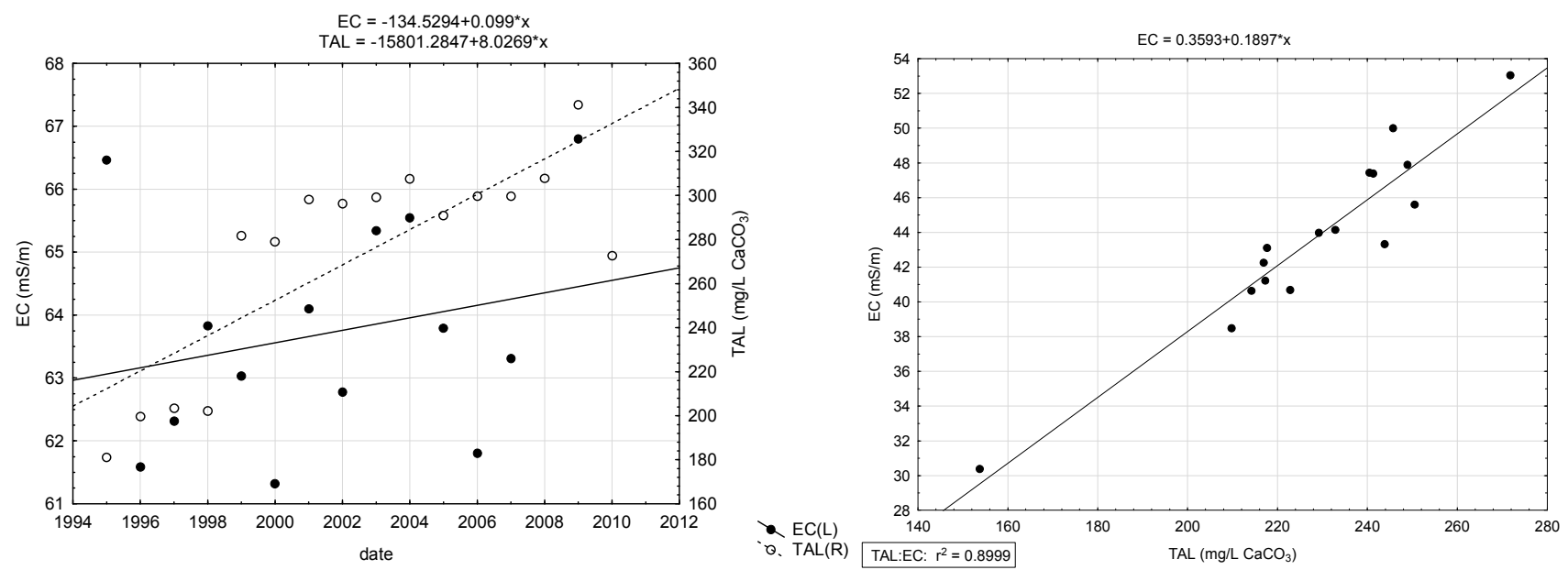

Figure 7

Changes in the annual average values of EC and TAL in Boskop Dam from 1995 to 2010, and the direct linear relationship between EC and TAL, $\left(r^{2}=0,8999 ; n=16\right)$ in Klerkskraal Dam.
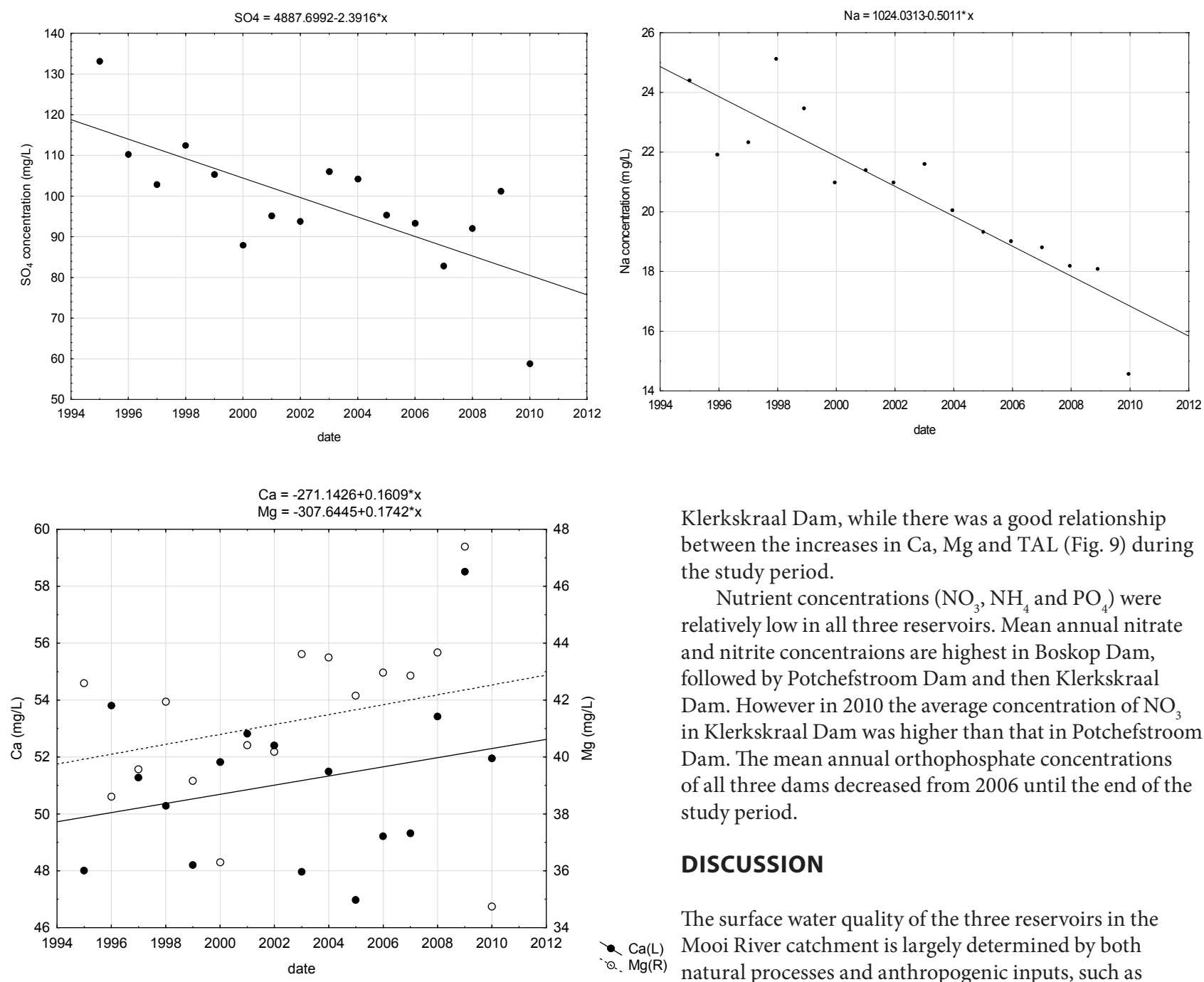

Klerkskraal Dam, while there was a good relationship between the increases in Ca, Mg and TAL (Fig. 9) during the study period.

Nutrient concentrations $\left(\mathrm{NO}_{3}, \mathrm{NH}_{4}\right.$ and $\left.\mathrm{PO}_{4}\right)$ were relatively low in all three reservoirs. Mean annual nitrate and nitrite concentraions are highest in Boskop Dam, followed by Potchefstroom Dam and then Klerkskraal Dam. However in 2010 the average concentration of $\mathrm{NO}_{3}$ in Klerkskraal Dam was higher than that in Potchefstroom Dam. The mean annual orthophosphate concentrations of all three dams decreased from 2006 until the end of the study period.

\section{DISCUSSION}

The surface water quality of the three reservoirs in the Mooi River catchment is largely determined by both natural processes and anthropogenic inputs, such as agricultural and mining pollutants. Klerkskraal Dam is mostly free from the impacts of mining pollution but is surrounded by crop farming and grazing. Boskop Dam can be both directly or indirectly impacted upon by the mining pollution from the WFS since much of the water from the WFS recharges the underlying karst aquifer of 


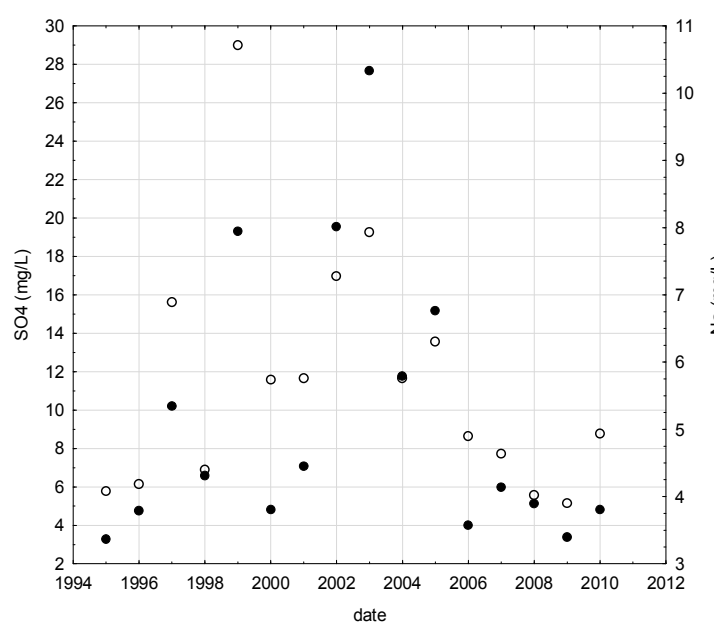

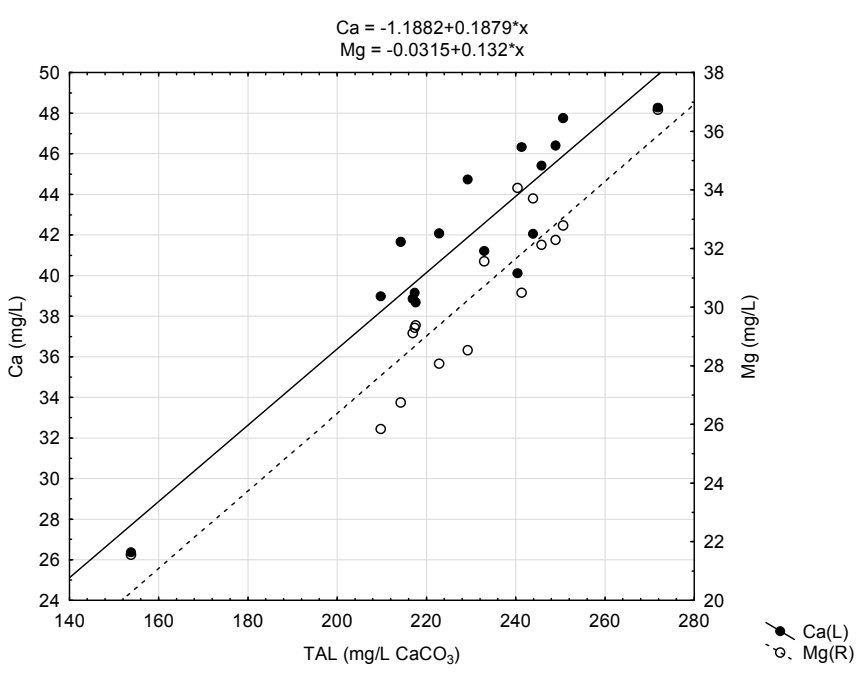

Figure 9

(a) Changes in the $\mathrm{SO}_{4}$ and Na concentrations in Klerkskraal Dam indicated no clear trends over the period 1995-2010. (b) There was a good direct relationship between the increase in TAL, and the increase in Ca and $\mathrm{Mg}$ concentrations during the same period in Klerkskraal Dam. the Boskop-Turffontein Compartment, and during high rainfall conditions the dam receives water directly from the highly polluted WFS. The Potchefstroom Dam is situated downstream of the Boskop Dam and therefore presents an accumulation point for all the upstream impacts of both agricultural and mining pollution.

The SOM of the water quality data of the three reservoirs once again emphasized the influence of mining-related effluents on the quality of the freshwater resources of the Boskop Dam and Potchefstroom Dam. When SOM mapping is performed the desired solutions or targets are not given and the network learns to cluster the data by recognising different patterns (Kalteh, et al., 2008). The mapping used 17 years' water quality data determined in three reservoirs and successfully clustered the data into clusters with common statistical properties. High concentrations of $\mathrm{SO}_{4}$, together with higher $\mathrm{EC}$ and TDS values, were evident in the Boskop and Potchefstroom Dams compared to Klerkskraal Dam, which is usually considered as upolluted.

In Klerkskraal Dam, which is situated above the confluence of the WFS, there is a strong direct relationship $\left(r^{2}=0.9\right)$ between EC and TAL (Fig. 7). TDS concentrations in natural waters are a result of dissolution from the soil and bedrock (Kney and Brandes, 2007 and references therein). Thus according to the hypothesis of Kney and Brandes (2007), we can conclude that Klerkskraal Dam is still a water source displaying a range of mostly natural/unpolluted conditions, where the directly related increases in EC,TDS and TAL may be explained by natural dissolution of the bedrock as well as the impacts of irrigation, dryland farming and the removal of natural vegetation by overgrazing of the surrounding catchment area. This is further supported by the good direct relationship that exists between the increase in TAL and the increase in $\mathrm{Ca}$ and $\mathrm{Mg}$ concentrations in this dam during the study period, given the dolomitic nature of the area. In comparison to the situation in Klerkskraal Dam, Boskop Dam presents a dam impacted upon by pollutants. It is clear from Fig. 7 that there will not be a direct correlation between EC and TAL. However, it was found that where $\mathrm{EC}$ was expected to show a higher increase compared to TAL due to continued mining pollution, it was in fact TAL that increased at a higher rate during the study period.
This result is supported by the slightly decreasing TDS levels observed in both Boskop and Potchefstroom Dams over the study period, combined with the slight increase in both $\mathrm{Ca}$ and $\mathrm{Mg}$ concentrations in these two reservoirs. This difference in the relationship between EC and TAL may thus be attributed to a lesser degree of pollution.

In 2002 Van der Walt et al. showed an increase in $\mathrm{SO}_{4}$ concentrations in Boskop Dam from 1968 to 1995, with concentrations of up to $160 \mathrm{mg} / \ell$. Mine effluents contain large quantities of sulphates which are discharged into natural resources of surface and ground waters (Durand, 2012). Cyanide in the form of $\mathrm{NaCN}$ is used in the process of gold extraction. After extraction ferrous sulphide or ferrous chloride is added to neutralise the cyanide (Durand, 2012). This results in a variety of chemicals that can eventually leach into rivers and reservoirs such as the Donaldson Dam (Durand, 2012 and references therein). During the current study both $\mathrm{SO}_{4}$ concentrations as well as $\mathrm{Na}^{+}$concentrations exhibited a decline from 1995 to 2010. Although the $\mathrm{SO}_{4}$ concentrations varied considerably during the study period in the Boskop and Potchefstroom Dams, no such trend could be recognised in Klerkskraal Dam.

\section{CONCLUSIONS}

The study was successful in identifying hydrochemical differences as well as changes that occurred in the water quality of Klerkskraal, Boskop and Potchefstroom Dams over the period 1995-2010. The SOM method revealed clear distinctions in the water quality of the three reservoirs in relation to the effect of mining pollution. Based on the relationship between EC, TAL and TDS the Klerkskraal Dam can still be considered as a water source displaying a range of natural, mostly unpolluted, conditions. From the changes observed in EC and TAL we further conclude that, although Boskop Dam still carries the burden of mining pollution via the WFS, the pollution levels of the freshwater of Boskop Dam have decreased from 1995 to 2010.

\section{ACKNOWLEDGEMENTS}

We would like to thank Marica Erasmus from the DWA for 
making the data available to us. We would also like to thank Christel Pretorius for creating the map for this study.

\section{REFERENCES}

ANNANDALE E and NEALER E (2011) Exploring aspects of the water history of the Potchefstroom region and the local management of it. New Contree 62 111-124.

CHAN WS, RECKNAGEL F, CAO H and PARK H-D (2007) Elucidation and short-term forecasting of microcystin concentrations in Lake Suwa (Japan) by means of artificial neural networks and evolutionary algorithms. Water Res. 41 2247-2255.

COETZEE H, WINDE F and WADE P (2006) An assessment of sources, pathways, mechanisms and risks of current and potential future pollution of water and sediments in gold mining areas of the Wonderfonteinspruit catchment (Gauteng/North West Province, South Africa). WRC Report No. 1214/1/06. Water Research Commission, Pretoria.

COETZEE H, WADE PW, NTSUME G and JORDAAN W (2002) Radioactivity study on sediments in a dam in the Wonderfonteinspruit catchment. Report to the Department of Water Affairs and Forestry (unpublished). Department of Water Affairs and Forestry, Pretoria.

CURRIE SL (2001) The implementation of an environmental decisionmaking support system: the Mooi River Catchment as a case study. PhD thesis, Potchefstroom University for Christian Higher Education. 152 pp.

DALLAS HF and DAY JA (2004) The effect of water quality variables on aquatic ecosystems: a review. WRC Report No. TT 224/04. Water Research Commission, Pretoria. 222 pp.

DWAF (DEPARTMENT OF WATER AFFAIRS AND FORESTRY, SOUTH AFRICA) (1996) South African water quality guidelines, Volumes 7 and 8. Department of Water Affairs and Forestry, Pretoria.

DWA (DEPARTMENT OF WATER AFFAIRS, SOUTH AFRICA) (2011) List of registered dams. URL: www.dwaf.gov.za (Accessed October 2011).

DWA (DEPARTMENT OF WATER AFFAIRS, SOUTH AFRICA) (2009) Adopt-a-River Programme Phase II: Development of an Implementation Plan. Water Resource Quality Situation Assessment. Resource Quality Services Project Number WP 9583. URL: http://www.dwaf.gov.za/iwqs/rhp/xtra/Water Quality Situation Assessments.pdf (Accessed July 2011).

DWA (DEPARTMENT OF WATER AFFAIRS, SOUTH AFRICA) (1986) Management of the Water Resources of the Republic of South Africa. Department of Water Affairs, Pretoria.

DWAF (DEPARTMENT OF WATER AFFAIRS AND FORESTRY, SOUTH AFRICA) (1999) Mooirivier Staatswaterskema Boskopdam, Damveiligheidsinspeksie. Department of Water Affairs and Forestry, Pretoria.

DURAND JF (2012) The impact of gold mining on the Witwatersrand on the rivers and karst system of Gauteng and North West Province, South Africa. J. Afr. Earth Sci. 68 24-43.

IIVARINEN J, KOHONEN T, KANGAS J and KASKI S (1994) Visualizing the clusters of self-organizing Map. In: Carlsson C, Järvi T and Reponen T (eds.) Proceedings of the Conference on Artificial Intelligence Research in Finland. Finnish Artificial Intelligence Society, Helsinki. 122-126.

IWQS (INSTITUTE FOR WATER QUALITY STUDIES) (1999) Report on the radioactivity monitoring programme in the Mooi River (Wonderfonteinspruit) catchment. Report No. N/C200/00/ RPQ/2399. Institute for Water Quality Studies, Department of Water Affairs and Forestry, Pretoria.
KALTEH AM, HJORTH P and BERNDTSSON R (2008). Review of the self-organizing map (SOM) approach in water resources: analysis, modelling and application. Environ. Model. Software 23 835-845.

KNEY AD and BRANDES D (2007) A graphical screening method for assessing stream water quality using specific conductivity and alkalinity data. J. Environ. Manage. 82 519-528.

KOHONEN T (1982) Self-organizing formation of topologically correct feature maps. Biol. Cybern. 43 59-69.

KOHONEN T (1988) Learning Vector Quantization. Neural Networks 1303.

KOHONEN T (1995) Self-Organizing Maps. Volume 30 of Springer Series in Information Sciences. Springer, Berlin.

KOHONEN T and HONKELA T (2007) Kohonen Network. Scholarpedia 2 (1) 1568.

KRAAIJVELD MA, MAO J and JAIN AK (1995) A nonlinear projection method based on Kohonen's topology preserving maps. IEEE Trans. Neural Networks 6 548-559.

LOUW A (2011a) Nog 'n myn begin prospekteer naby Potchefstroom. Potchefstroom Herald, 22 April 2011. 3.

LOUW A (2011b) Boere boos oor myne. Potchefstroom Herald, 20 May 2011. 2

RECKNAGEL F, WELK A, KIM B and TAKAMURA N (2006) Artificial neural network approach to unravel and forecast algal population dynamics of two lakes different in morphometry and eutrophication. In: Recknagel F (ed.) Ecological Informatics ( $2^{\text {nd }}$ edn.). Springer-Verlag, Berlin. 325-345.

STATSOFT, INC. (2012) STATISTICA (data analysis software system), version 11. www.statsoft.com.

ULTSCH A and SIEMON HP (1990) Kohonen's self organizing feature maps for exploratory data analysis. In: Proceedings of International Neural Network Conference (INNC-90), Paris, France, July 9-13, 1990. Kluwer, Dordrecht, The Netherlands. 305-308.

VAN GINKEL CE (2008) Investigating the application of ecological informatics modelling techniques for predicting harmful algal blooms in hypertrophic reservoirs of South Africa. PhD thesis, North-West University, Potchefstroom.

VAN DER WALT IJ, WINDE F and NELL B (2002) Integrated catchment management: the Mooi River (Northwest Province, South Africa). A case study. Cuadernos de Investigacion Geografica $\mathbf{2 8}$ $109-126$.

VESANTO J (2000) Neural network tool data mining: SOM Toolbox. In: Proceedings of Symposium on Tool Environments and Development Methods for Intelligent Systems (TOOLMET2000). Oulun Yliopistopaino, Oulu, Finland. 184-196.

VESANTO J, HIMBERG J, ALHONIEMI E and PARHANKAGAS J (2000) SOM Toolbox for Matlab 5, Report A57. URL: http://www. cis.hut.fi/projects/somtoolbox/S (Accessed August 2012).

WADE P, WOODBOURNE S, MORRIS WM, VOS P and JARVIS NV (2002) Tier 1 risk assessment of radionuclides in selected sediments of the Mooi River. WRC Report No. 1095/1/02. Water Research Commission, Pretoria.

WADE P, WINDE F and COETZEE H (2004): Risk assessment. In: Coetzee H (ed.) An assessment of sources, pathways, mechanisms and risks of current and potential future pollution of water and sediments in gold-mining areas of the Wonderfonteinspruit catchment. WRC Report No 1214/1/06. Water Research Commission, Pretoria. 119-165.

WINDE F (2010a) Uranium pollution of the Wonderfonteinspruit: 1997-2008. Part 1: Uranium in water - concentrations, loads and associated risks. Water SA 36 (3) 239-256.

WINDE F (2010b) Uranium pollution of the Wonderfonteinspruit: 1997-2008. Part 2: Uranium in water - concentrations, loads and associated risks. Water SA 36 (3) 257-278. 